\title{
Ecophysiological responses of juvenile summer and winter flounder to hypoxia: experimental and modeling analyses of effects on estuarine nursery quality
}

\author{
Kevin L. Stierhoff ${ }^{1,2}$, Timothy E. Targett ${ }^{1, *}$, KerriLynn Miller ${ }^{1,3}$ \\ ${ }^{1}$ University of Delaware, College of Marine and Earth Studies, Lewes, Delaware 19958, USA \\ ${ }^{2}$ Present address: NOAA Fisheries, Southwest Fisheries Science Center, Fisheries Ecology Division, 110 Shaffer Rd, \\ Santa Cruz, California 95060, USA \\ ${ }^{3}$ Present address: Nicholas School of the Environment and Earth Sciences, Duke University, Box 90328 Duke University, \\ Levine Science Research Center, Durham, North Carolina 27708, USA
}

\begin{abstract}
Growth and feeding rates were measured in juvenile summer flounder Paralichthys dentatus and winter flounder Pseudopleuronectes americanus exposed to sub-lethal hypoxia (low dissolved oxygen, DO) over a range of temperatures, to determine its potential effects on nursery habitat quality for these 2 estuary-dependent flatfishes. Growth rates of both species were generally reduced as DO decreased, particularly at DO levels of 50 to $70 \%$ air saturation, and as temperature increased. Summer flounder were more tolerant of low DO than were winter flounder at both 20 and $25^{\circ} \mathrm{C}$. At these temperatures, summer flounder growth was reduced by $\sim 25 \%$ (compared to growth at normoxia [7.0 $\mathrm{mg} \mathrm{O}_{2} \mathrm{l}^{-1}$ ]) at $3.5 \mathrm{mg} \mathrm{O}_{2} \mathrm{l}^{-1}$ and by 50 to $60 \%$ at $2.0 \mathrm{mg} \mathrm{O}_{2} \mathrm{l}^{-1}$. In contrast, growth of winter flounder at $20^{\circ} \mathrm{C}$ was reduced by $\sim 50 \%$ at both 3.5 and $5.0 \mathrm{mg} \mathrm{O}_{2} \mathrm{l}^{-1}$, and growth was zero at $2.0 \mathrm{mg} \mathrm{O}_{2} \mathrm{l}^{-1}$. At $25^{\circ} \mathrm{C}$, winter flounder grew poorly in all DO treatments and lost weight at $2.0 \mathrm{mg} \mathrm{O} \mathrm{O}^{-1}$. Summer flounder were also tested at $30^{\circ} \mathrm{C}$. Growth was significantly reduced even at $5.0 \mathrm{mg} \mathrm{O}_{2} \mathrm{l}^{-1}$, and was reduced by $\sim 90 \%$ at $2.0 \mathrm{mg} \mathrm{O}_{2} \mathrm{l}^{-1}$. A significant relationship between feeding rate and growth suggested reduced consumption to be a major cause of growth limitation under hypoxia. There was no evidence of growth acclimation for either species after 7 to $14 \mathrm{~d}$ exposure to hypoxia. The effect of hypoxia on growth of summer flounder was reduced at lower salinity (15 vs. $25 \%$ ) and was unaffected by the presence of a sand substrate. Similarity between modeled growth under hypoxic conditions, based on our laboratory results, and observed growth of summer flounder in a hypoxic estuarine tributary suggests growth limitation in the wild. These laboratory and field results demonstrate that even moderate hypoxia can adversely affect growth rates, and thus the quality of estuarine nursery habitats for juvenile flatfishes.
\end{abstract}

KEY WORDS: Hypoxia - Summer flounder - Winter flounder - Flatfish • Essential fish habitat · Nursery habitat · Growth limitation

\section{INTRODUCTION}

Shallow coastal ecosystems, such as estuaries and coastal bays, serve as important nursery habitats for the larval and juveniles stages of a variety of estuarydependent fishes (Weinstein 1979, Hoss \& Thayer 1993, Able 1999, Minello 1999). Nurseries are considered to be a subset of all juvenile habitats that con- tribute disproportionately to recruitment to the adult population (Beck et al. 2001). The functional value of estuarine habitats as nurseries is attributed primarily to physicochemical regimes (e.g. temperature and salinity) that are physiologically suitable or optimal, abundant prey resources, and low predation risk, conditions that promote rapid growth and enhance survival of young fishes (Joseph 1973, Miller et al. 1985). In his 
review, Gibson (1994) conjectured that the availability of quality nursery habitat in sufficient quantity has a major influence on subsequent recruitment, particularly for flatfishes.

Degradation of estuarine water quality threatens the availability and quality of nursery habitats for estuarydependent fishes. Kennish (2002) listed habitat loss and eutrophication (and associated hypoxia [low dissolved oxygen, DO] and anoxia) as the 2 greatest threats to estuarine environments. It is currently estimated that two-thirds of coastal rivers and bays in the USA are moderately to severely degraded from nutrient pollution (Bricker et al. 1999).

As a result, hypoxia has become increasingly common in estuarine and coastal marine ecosystems (Diaz \& Rosenberg 1995, Diaz 2001). Hypoxia may be chronic, lasting for periods of days to months (Officer et al. 1984, Diaz 2001), or fluctuate over the diel (24 h) cycle (D'Avanzo \& Kremer 1994, Tyler 2004). Chronic hypoxia results from respiration and decomposition of organic material below the pycnocline in a densitystratified water column with limited vertical exchange, whereas diel-cycling DO is driven by day-night cycles of photosynthesis and respiration of phytoplankton and macroalgae. Given the widespread nature and increasing severity of coastal hypoxia, considerable resources are being devoted in the USA to understanding its effects on the biology and ecology of resident fauna (NRC 2000).

Hypoxia can affect resident fish communities in several ways. The most obvious effects of low DO are those relatively rare but extreme cases that result in large-scale mortality of fish and shellfish (Seliger et al. 1985, Paerl et al. 1998). Less evident, but perhaps more important over broader temporal and spatial scales, are the sub-lethal effects of moderate hypoxia (either constant or diel-cycling) on the quality and quantity of nursery habitats. For juvenile fishes, effects of hypoxia are manifested through reduced feeding and growth rates (Chabot \& Dutil 1999, Pichavant et al. 2001, McNatt \& Rice 2004), altered behavior (Kramer 1987, Wannamaker \& Rice 2000, Tyler 2004), and/or habitat compression (Eby \& Crowder 2002, Tyler 2004, Bell \& Eggleston 2005). Physicochemical conditions such as hypoxia could affect survival rates and recruitment through subtle effects on growth rate and stage duration of larval and juvenile fishes (Houde 1987, 1989). Since mortality during early life is largely a sizedependent phenomenon (Anderson 1988, Sogard 1997), hypoxia-induced growth limitation can have substantial negative effects on the value of nursery habitat for young estuary-dependent fishes through decreased survival and recruitment.

Although it is generally understood that hypoxia affects the growth of fishes, low DO concentrations that significantly limit growth vary greatly among species (Poucher \& Coiro 1997, US EPA 2000). A significant shortcoming of many previous studies is the comparison of relatively few DO concentrations, which thus restricts the ability to precisely identify those DO levels at which growth rate is negatively affected and to identify those species most sensitive to hypoxia. Furthermore, few studies have considered the interaction of hypoxia with other environmental factors affecting growth in juvenile fishes (e.g. temperature, salinity) and their potential combined effect on nursery habitat quality.

Summer flounder Paralichthys dentatus and winter flounder Pseudopleuronectes americanus are economically and ecologically important estuary-dependent flatfishes whose geographic ranges overlap in the MidAtlantic Bight (USA), and whose juveniles inhabit estuaries during late spring and summer when hypoxic events occur most frequently. Juvenile summer flounder occur in greatest abundance from Cape Cod, Massachusetts, to Cape Hatteras, North Carolina (Packer \& Hoff 1999), whereas juvenile winter flounder are distributed further north and are abundant from Canada (Richards \& Castagna 1970) then south to the eastern shore of Virginia, USA (Howell \& Canario 1987). Limited information is available to describe the effects of sub-lethal hypoxia on growth rates of either species. Bejda et al. (1992) observed a reduction in growth rate of juvenile winter flounder at a single low DO level (2.2 $\left.\mathrm{mg} \mathrm{O}_{2} \mathrm{l}^{-1}\right)$ and under diel-cycling hypoxia conditions (2.5 to $6.4 \mathrm{mg} \mathrm{O}_{2} \mathrm{l}^{-1}$ ). To our knowledge, no information is currently available on the effects of DO on growth of summer flounder.

In this study, we determined the sub-lethal effects of hypoxia on growth and feeding rates of juvenile summer and winter flounder in the laboratory. The overall objective was to examine the potential effects of low DO on nursery habitat quality for these 2 estuarydependent flatfishes. Each species was exposed to several degrees of constant and diel-cycling hypoxia at several temperatures, in order to investigate potential seasonal effects or latitudinal differences in hypoxia sensitivity across their geographic ranges. In addition, we examined the potential effects of salinity and the presence of a sand substrate on the growth response of summer flounder to hypoxia. Finally, growth rates of summer flounder were modeled under various DO conditions to illustrate the potential effect of long-term hypoxia exposure on size-at-age. Growth rates of juvenile summer flounder under various DO conditions (based on laboratory growth rates) were compared to observed lengths of summer flounder collected from a hypoxic estuarine tributary in order to determine whether hypoxia-induced growth limitation was evident in the wild. 


\section{MATERIALS AND METHODS}

Juvenile summer flounder and winter flounder were collected from Pepper Creek in the Delaware Coastal Bays, and also from Delaware Bay (near Lewes, Delaware, USA) between April and June 2001, 2003, and 2004. Fish were acclimated in the laboratory to experimental temperatures ( $\geq 14 \mathrm{~d}$ ) and salinities ( $\geq 7 \mathrm{~d}$ ) before experiments. Fish were held at a 14:10 h light:dark photoperiod and fed frozen mysid shrimp Mysis relicta ad lib twice daily during acclimation.

Laboratory growth experiments. Interaction of temperature and $D O$ on growth and feeding: The interaction of temperature and DO on growth and feeding rates of juvenile summer flounder $\left(20,25\right.$, and $\left.30^{\circ} \mathrm{C}\right)$ and winter flounder $\left(20\right.$ and $\left.25^{\circ} \mathrm{C}\right)$ were examined at a salinity of $25 \%$. Juvenile winter flounder were not tested at $30^{\circ} \mathrm{C}$ owing to high mortality during acclimation under normoxic conditions. Each species was exposed to 5 DO treatments: normoxia $\left(7.0 \mathrm{mg} \mathrm{O}_{2} \mathrm{l}^{-1}\right)$, 3 levels of constant hypoxia $\left(2.0,3.5\right.$, and $\left.5.0 \mathrm{mg} \mathrm{O}_{2} \mathrm{l}^{-1}\right)$, and diel-cycling hypoxia (2.0 to $11.0 \mathrm{mg} \mathrm{O}_{2} \mathrm{l}^{-1}$ ). Minimum $\left(2.0 \mathrm{mg} \mathrm{O}_{2} \mathrm{l}^{-1}\right)$ and maximum $\left(11.0 \mathrm{mg} \mathrm{O}_{2} \mathrm{l}^{-1}\right) \mathrm{DO}$ concentrations in the diel-cycling treatment coincided with the beginning of the light $(07: 00 \mathrm{~h})$ and dark $(21: 00 \mathrm{~h})$ periods, respectively. These DO treatments were chosen to approach the lethal concentrations for each species and, in the diel-cycling treatments, closely approximate natural DO conditions in shallow, Mid-Atlantic Bight estuaries (D'Avanzo \& Kremer 1994, Tyler 2004). DO was regulated using a computercontrolled device described in detail by Grecay \& Stierhoff (2002). This device simultaneously regulated DO in five 5001 recirculating aquarium systems. Each aquarium system had ten $18 \mathrm{l}$ tanks that held 1 fish each. The DO in each system was measured every 10 min and, if adjustment was necessary, DO was increased or decreased by the addition of either compressed $\mathrm{O}_{2}$ or $\mathrm{N}_{2}$ gas to the head reservoir. Stable DO levels were maintained throughout each experiment (Table 1). DO levels in each system were verified twice daily using a Yellow Springs Instruments Model 55 hand-held meter. There were no notable changes in $\mathrm{pH}$ during any of the experiments.

Juvenile summer flounder (55 to $90 \mathrm{~mm}$ standard length, SL) or winter flounder ( 35 to $67 \mathrm{~mm} \mathrm{SL}$ ) were acclimated in each of 5 aquarium systems (1 fish per tank; 10 fish per system) for $72 \mathrm{~h}$ before each experiment. DO concentration in each system was decreased to treatment levels during the final $24 \mathrm{~h}$ of acclimation. Fish were then exposed to treatment DO levels for $14 \mathrm{~d}$ and fed frozen Mysis relicta ad lib twice daily (09:00 and 17:00 h). Food was always available except for the $15 \mathrm{~h}$ prior to initial and final weighing, in order to minimize the effects of stomach contents on growth estimates.
Table 1. Paralichthys dentatus and Pseudopleuronectes americanus. Temperature, dissolved oxygen (DO) treatment, and actual DO concentration in juvenile summer flounder and winter flounder feeding and growth experiments. Constant treatments: mean DO calculated from triplicate measurements taken twice daily using a handheld DO meter; Dielcycling treatments: mean DO calculated from triplicate measurements taken at 07:00 h (min. DO) and 21:00 h (max. DO)

\begin{tabular}{|c|c|c|c|}
\hline \multirow[t]{2}{*}{$\begin{array}{l}\text { Temp. } \\
\left({ }^{\circ} \mathrm{C}\right)\end{array}$} & \multirow[t]{2}{*}{$\begin{array}{l}\text { Treatment } \\
\left(\mathrm{mg} \mathrm{O}_{2} \mathrm{l}^{-1}\right)\end{array}$} & \multicolumn{2}{|c|}{$\begin{array}{c}\text { Mean }( \pm \mathrm{SE}) \mathrm{DO} \\
\left(\mathrm{mg} \mathrm{O}_{2} \mathrm{l}^{-1}\right)\end{array}$} \\
\hline & & Week 1 & Week 2 \\
\hline \multicolumn{4}{|c|}{ P. dentatus } \\
\hline \multirow[t]{6}{*}{20} & 2.0 & $2.36(0.39)$ & $2.11(0.19)$ \\
\hline & 3.5 & $3.74(0.25)$ & $3.62(0.10)$ \\
\hline & 5.0 & $5.00(0.22)$ & $4.92(0.12)$ \\
\hline & 7.0 & $6.75(0.22)$ & $6.85(0.10)$ \\
\hline & Diel (min.) & $2.99(0.34)$ & $2.89(0.45)$ \\
\hline & Diel (max.) & $8.59(0.63)$ & $7.68(1.11)$ \\
\hline \multirow[t]{6}{*}{25} & 2.0 & $2.10(0.14)$ & $1.82(0.27)$ \\
\hline & 3.5 & $3.43(0.16)$ & $3.19(0.26)$ \\
\hline & 5.0 & $4.78(0.13)$ & $4.46(0.27)$ \\
\hline & 7.0 & $6.46(0.36)$ & $6.34(0.60)$ \\
\hline & Diel (min.) & $3.40(1.33)$ & $3.15(1.27)$ \\
\hline & Diel (max.) & $10.49(1.38)$ & $9.18(0.39)$ \\
\hline \multirow[t]{6}{*}{30} & 2.0 & $2.18(0.20)$ & $2.05(0.10)$ \\
\hline & 3.5 & $3.55(0.17)$ & $3.43(0.13)$ \\
\hline & 5.0 & $5.03(0.17)$ & $4.85(0.16)$ \\
\hline & 7.0 & $6.95(0.27)$ & $6.64(0.17)$ \\
\hline & Diel (min.) & $2.76(0.98)$ & $2.17(0.20)$ \\
\hline & Diel (max.) & $11.72(1.02)$ & $9.41(0.53)$ \\
\hline \multicolumn{4}{|c|}{ P. americanus } \\
\hline \multirow[t]{6}{*}{20} & 2.0 & $2.13(0.21)$ & $1.93(0.11)$ \\
\hline & 3.5 & $3.60(0.19)$ & $3.39(0.16)$ \\
\hline & 5.0 & $5.07(0.18)$ & $4.86(0.17)$ \\
\hline & 7.0 & $7.04(0.18)$ & $6.82(0.19)$ \\
\hline & Diel (min.) & $2.33(0.17)$ & $2.26(0.29)$ \\
\hline & Diel (max.) & $10.59(0.23)$ & $10.31(0.44)$ \\
\hline \multirow[t]{6}{*}{25} & 2.0 & $2.10(0.15)$ & $6.65(0.30)$ \\
\hline & 3.5 & $3.51(0.10)$ & $4.61(0.40)$ \\
\hline & 5.0 & $4.92(0.10)$ & $3.30(0.15)$ \\
\hline & 7.0 & $6.77(0.14)$ & $2.06(0.16)$ \\
\hline & Diel (min.) & $3.04(1.50)$ & $3.19(1.34)$ \\
\hline & Diel (max.) & 9.99 (0.69) & $9.47(0.79)$ \\
\hline
\end{tabular}

Uneaten food was removed and replaced with fresh food during the 09:00 $\mathrm{h}$ feeding, in order to maintain food and water quality. The specific growth rate (SGR) and linear growth rate (LGR) (see 'Response variables', below) of each fish were calculated for each of two $7 \mathrm{~d}$ growth periods using the initial, midpoint (Day 7), and final (Day 14) mass and length, respectively. Growth rates calculated over each $7 \mathrm{~d}$ growth period were compared to examine the potential that either species could adapt physiologically (i.e. by increasing growth rate) during prolonged exposure to low DO.

The use of frozen Mysis relicta as food in these experiments prohibited precise estimates of massspecific consumption rate (i.e. \% body mass $\mathrm{d}^{-1}$ ). 
Degradation of uneaten $M$. relicta made quantification of uneaten food impossible. Instead, mass-specific fecal production (FP) was used as a proxy for feeding rate. Stierhoff et al. (2003) successfully used this method to estimate feeding rate in experiments on mummichog Fundulus heteroclitus. Fecal material produced by each fish was removed by pipette daily at 09:00 h and frozen. All fecal material for each fish was pooled to calculate mean absorption efficiency (AE) and FP (see 'Response variables', below). Dry mass and ashed mass of fecal material for AE and FP calculations were obtained after being dried at $50^{\circ} \mathrm{C}$ (at least $24 \mathrm{~h}$ ) and oxidized at $450^{\circ} \mathrm{C}(24 \mathrm{~h})$.

Growth rate (SGR and LGR) and FP data were analyzed using 2-way analysis of covariance (ANCOVA) with DO and growth period (i.e. Week 1 vs. Week 2) as main factors and initial fish mass as the covariate. Significant differences (1) among DO treatments and (2) between growth periods within DO treatments were determined using Tukey's multiple comparison test ( $\alpha=0.05$ ). The effect of FP on SGR was determined using simple linear regression analysis. Data used in all analyses were normally distributed (determined by 1-sample Kolmogorov-Smirnov tests using the Lilliefors option). SGR data were logarithmically transformed $\left[\log _{10}(S G R+1)\right]$ as necessary to reduce heteroscedasticity. All statistical analyses were conducted using SPSS software.

Interaction of salinity and DO on growth and feeding: Juvenile summer flounder (60 to $93 \mathrm{~mm} \mathrm{SL}$ ) were grown under constant and diel-cycling hypoxia at $30^{\circ} \mathrm{C}$ and a salinity of $15 \%$, for comparison with growth rates at $30^{\circ} \mathrm{C}$ and a salinity of $25 \%$ from the previously described experiment. Feeding and acclimation procedures for this experiment were the same as those above. Growth rate and FP data were analyzed using a 2-way ANCOVA with DO and salinity as main factors and initial mass as the covariate. Significant differences between DO treatments and between salinities within DO treatments were determined using Tukey's multiple comparison test $(\alpha=0.05)$.

Interaction of substrate and DO on growth: To examine the interaction of substrate and DO on SGR and LGR, juvenile summer flounder (82 to $133 \mathrm{~mm} \mathrm{SL}$ ) were grown at $2 \mathrm{DO}$ levels (2.0 and $\left.7.0 \mathrm{mg} \mathrm{O}_{2} \mathrm{l}^{-1}\right)$ in the presence and absence of sand substrate for $7 \mathrm{~d}$. Two groups of fish (sand and no sand) were acclimated for $14 \mathrm{~d}$ at $25^{\circ} \mathrm{C}$ and a salinity of $25 \%$. Again, feeding and acclimation procedures were the same as those decribed above. However, FP was not quantified in this experiment, owing to the difficulties of accurately collecting fecal material from tanks that contained sand. Sand was rinsed and soaked in fresh water, sieved using a $100 \mu \mathrm{m}$ sieve, and dried for at least $24 \mathrm{~h}$ before being placed into tanks. The amount of sand was adequate to cover tank bottoms and was of sufficient depth for fish to bury.

Data were analyzed using 2-way ANCOVA with DO and substrate type (sand or no sand) as main factors and initial mass as the covariate. Significant differences between groups were determined using Tukey's multiple comparison test ( $\alpha=0.05)$.

Response variables: SGR (\% mass $d^{-1}$ ) was calculated from the instantaneous growth rate $(G)$ as: SGR = $\left(\mathrm{e}^{G}-1\right) \times 100$, where $G=\left(\ln M_{\mathrm{f}}-\ln M_{\mathrm{i}}\right) \times d^{-1}, M_{\mathrm{f}}=$ final wet mass, $M_{\mathrm{i}}=$ initial wet mass, and $d=$ duration of the experiment in days (Ricker 1975). LGR $\left(\mathrm{mm} \mathrm{d}^{-1}\right)$ was calculated as: $\mathrm{LGR}=\left(L_{\mathrm{f}}-L_{\mathrm{i}}\right) \times d^{-1}$, where $L_{\mathrm{f}}=$ final $\mathrm{SL}$, and $L_{\mathrm{i}}=$ initial SL. AE (\%) was calculated as: $\mathrm{AE}=$ $100 \times\left[1-\left(\%\right.\right.$ ash in food $\times \%$ ash in feces $\left.\left.^{-1}\right)\right]$. Mass-specific FP ( $\mathrm{g}$ feces $\times \mathrm{g}$ fish $^{-1}$ ) over each $7 \mathrm{~d}$ growth period was calculated for each fish as: FP $=F_{\text {dm }}$ (mean fish mass $)^{-1}$, where $F_{\mathrm{dm}}=$ total dry mass of feces, and mean fish mass is the average of initial and final masses.

Modeled and in situ growth of juvenile summer flounder. Using growth rates of juvenile summer flounder from laboratory experiments at $25^{\circ} \mathrm{C}$, growth in mass and length (beginning at $60 \mathrm{~mm} \mathrm{SL}$ and $3.25 \mathrm{~g})$ was modeled under constant $(2.0,3.5,5.0$, and $7.0 \mathrm{mg} \mathrm{O}_{2} \mathrm{l}^{-1}$ ) and diel-cycling (2.0 to $11.0 \mathrm{mg} \mathrm{O}_{2} \mathrm{l}^{-1}$ ) DO conditions over $80 \mathrm{~d}$, which represents an approximate nursery period for summer flounder. The results from the $25^{\circ} \mathrm{C}$ experiment were chosen for the model in order to most closely approximate conditions experienced by fishes in Pepper Creek during the collection period (see below). Since the SGR of summer flounder was similar at 5.0 and $7.0 \mathrm{mg} \mathrm{O}_{2} \mathrm{l}^{-1}$, model output for $5.0 \mathrm{mg} \mathrm{O}_{2} \mathrm{l}^{-1}$ was removed for visual clarity. Body mass in the model was calculated as: $M_{t}=M_{t-1}$ $\times \mathrm{e}^{(G t)}$, where $M_{t}=$ current mass, $M_{t-1}=$ mass the previous day, $G=$ instantaneous growth rate, and $t=$ time in days. The value of $G$ in the model was adjusted each day using the allometric growth equation: $G=$ $G_{0} \times\left(M_{t-1}\right)^{b}$, where $G_{0}=$ instantaneous growth rate on Day 0 , and $b=$ the mass exponent. Since $b$ was not known for summer flounder, the value of $b=-0.49$ for juvenile Japanese flounder Paralichthys olivaceus (Yamashita et al. 2001) was used. Total length (TL) in the model was calculated as: $\mathrm{TL}_{t}=\mathrm{TL}_{t-1}+(\mathrm{LGR} \times t)$, where $\mathrm{TL}_{t-1}=$ initial length $(60 \mathrm{~mm})$. Both mass and length models assume constant exposure to each DO level for the $80 \mathrm{~d}$ period.

To examine whether juvenile summer flounder grow sub-optimally in the wild, LGR of fish from the laboratory experiments was compared to those of fish collected from Pepper Creek, a hypoxic estuarine tributary in the Delaware Coastal Bays. Linear regression analysis was used to calculate LGR of juveniles collected during a trawl survey in Pepper Creek between 9 May and 27 June 2001 (Tyler 2004). Regression 
slopes from modeled and field-collected fish were compared using 1-way ANCOVA with DO as the main factor and date as the covariate. A significant interaction between factors (DO $\times$ Date) indicated heterogeneity among slopes. Additional ANCOVA were conducted to identify pairs of slopes that were statistically different. A significance level of $\alpha=0.05$ was used in all analyses.

\section{RESULTS}

\section{Laboratory growth experiments}

Effects of DO and temperature on growth and feeding rates

Growth of summer flounder at 20 and $25^{\circ} \mathrm{C}$ was significantly reduced at $3.5 \mathrm{mg} \mathrm{O}_{2} \mathrm{l}^{-1}$ (by $25 \%$ compared to growth at $7.0 \mathrm{mg} \mathrm{O}_{2} \mathrm{l}^{-1}$ ) and $2.0 \mathrm{mg} \mathrm{O}_{2} \mathrm{l}^{-1}$ (by 50 to $60 \%$ ) (ANCOVA, p < 0.05) (Fig. 1). Growth rate was most affected by low DO at $30^{\circ} \mathrm{C}$ : a significant reduc-
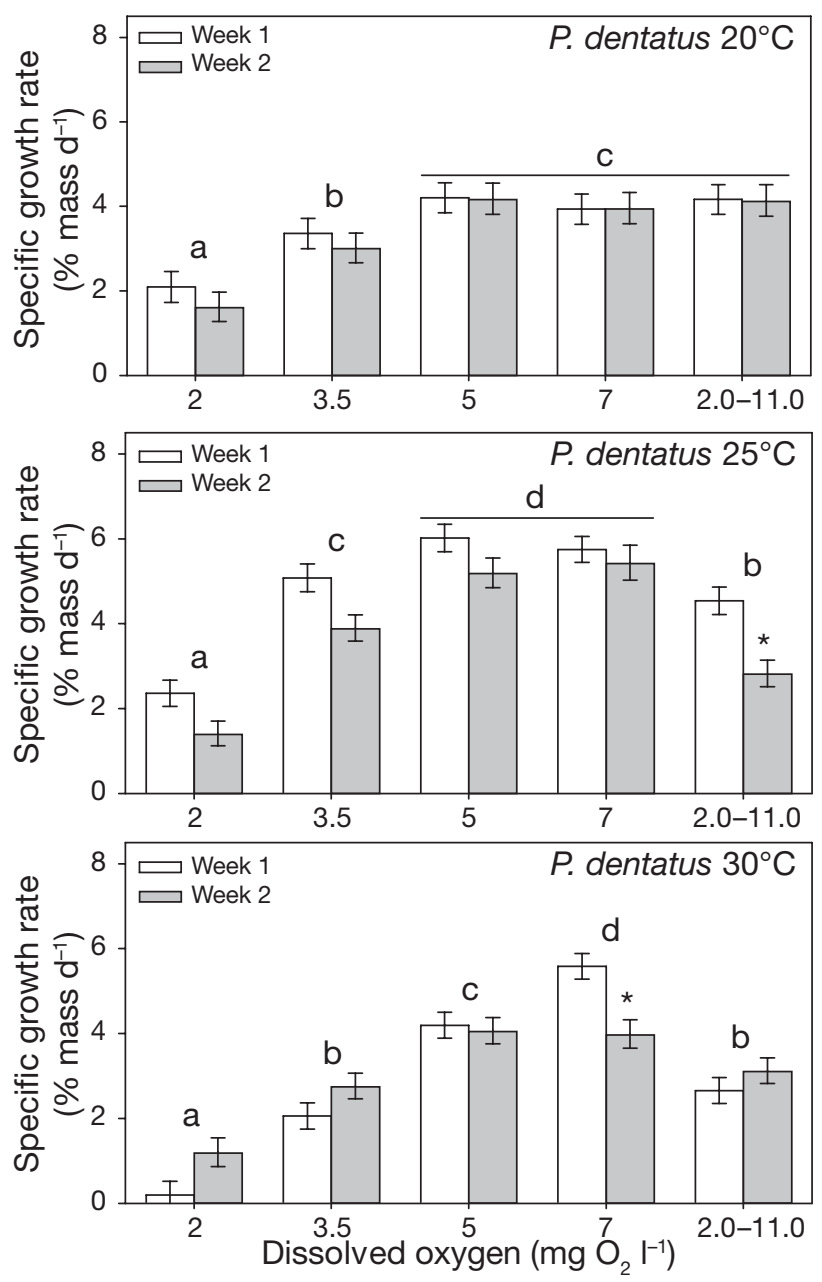

tion in SGR was observed at $5.0 \mathrm{mg} \mathrm{O}_{2} \mathrm{l}^{-1}$, and SGR was reduced by $\sim 90 \%$ at $2.0 \mathrm{mg} \mathrm{O}_{2} \mathrm{l}^{-1}$. There was no effect of diel-cycling DO on SGR of summer flounder at $20^{\circ} \mathrm{C}$, but SGR was significantly reduced (by $\sim 35 \%$ ) in the diel-cycling treatment at both 25 and $30^{\circ} \mathrm{C}$. SGR generally increased with temperature and decreased with DO (Fig. 2). The combination of high temperature $\left(30^{\circ} \mathrm{C}\right)$ and low DO $\left(2.0 \mathrm{mg} \mathrm{O} \mathrm{O}^{-1}\right)$ resulted in particularly low SGR. The response of summer flounder LGR was similar to that of SGR for all DO/temperature combinations (Table 2).

Growth of winter flounder at $20^{\circ} \mathrm{C}$ was significantly reduced at 3.5 and $5.0 \mathrm{mg} \mathrm{O}_{2} \mathrm{l}^{-1}$ and in the diel-cycling treatment (by $\sim 50$ to $60 \%$ ) (ANCOVA, p < 0.05) (Fig. 1). Fish at $20^{\circ} \mathrm{C}$ did not grow at $2.0 \mathrm{mg} \mathrm{O}_{2} \mathrm{l}^{-1}$. Growth rates of winter flounder at $25^{\circ} \mathrm{C}$ were less than $1 \%$ body mass $\mathrm{d}^{-1}$ across all DO treatments, and at $2.0 \mathrm{mg} \mathrm{O}_{2} \mathrm{l}^{-1}$ growth was considerably negative (Fig. 1). Similar to summer flounder, the combination of high temperature $\left(25^{\circ} \mathrm{C}\right.$ in the case of winter flounder, as they exhibited high mortality during acclimation to $30^{\circ} \mathrm{C}$ at normoxia) and low DO resulted in particularly low growth. The
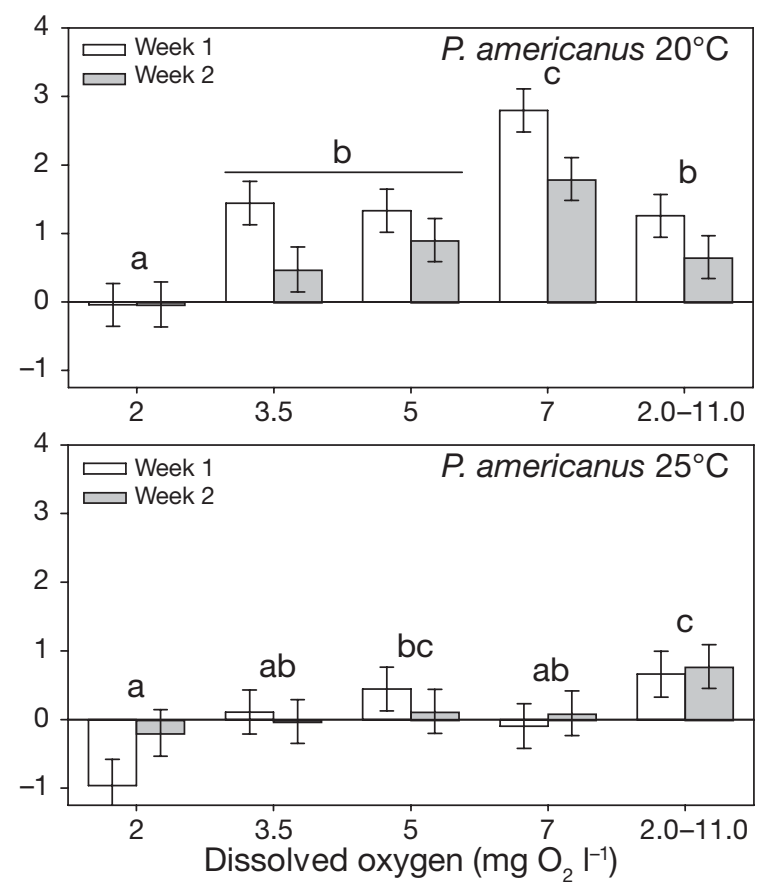

Fig. 1. Paralichthys dentatus and Pseudopleuronectes americanus. Specific growth rates $\left(\mathrm{SGR}_{i}\right.$ mean $\left.\pm \mathrm{SE}\right)$ of juvenile summer flounder and winter flounder across dissolved oxygen (DO) and temperature treatments. DO treatments with similar superscripts are not statistically different. *Significant differences between Weeks 1 and 2 (Tukey's multiple comparisons test) 


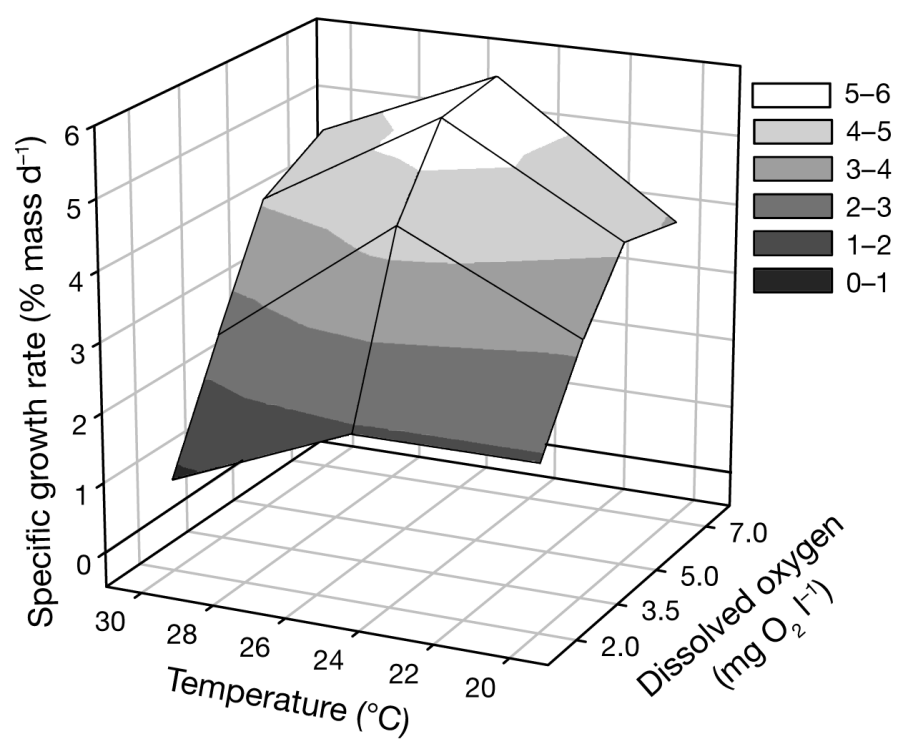

Fig. 2. Paralichthys dentatus. Interactive effects of temperature and dissolved oxygen on the specific growth rate of juvenile summer flounder

response of LGR was similar to SGR for winter flounder for all DO/temperature combinations (Table 2).

Neither summer flounder nor winter flounder exhibited growth acclimation to low DO at any temperature during the $14 \mathrm{~d}$ exposure. Acclimation would have been evident as compensatory (greater) growth during the second week's exposure to hypoxia. At $20^{\circ} \mathrm{C}$, SGR of summer flounder remained relatively constant over the two $7 \mathrm{~d}$ growth periods in all DO treatments (Fig. 1). Growth of summer flounder at $25^{\circ} \mathrm{C}$ and winter flounder at $20^{\circ} \mathrm{C}$ decreased significantly between Week 1 and Week 2 (significant overall effect of growth period; ANCOVA, $p<0.05$ ), but significant differences be-

Table 2. Paralichthys dentatus and Pseudopleuronectes americanus. Linear growth rate (LGR, $\mathrm{mm} \mathrm{d}^{-1}$ ) of juvenile summer flounder and winter flounder after $14 \mathrm{~d}$ exposure to temperature and DO treatment combinations. Means with similar superscripts are not statistically different $(p>0.05)$

\begin{tabular}{|c|c|c|c|}
\hline \multirow{2}{*}{$\begin{array}{l}\text { Treatment } \\
\left(\mathrm{mg} \mathrm{O}_{2} \mathrm{l}^{-1}\right)\end{array}$} & \multirow[b]{2}{*}{$20^{\circ} \mathrm{C}$} & lean $( \pm \mathrm{SE})$ LGR & \multirow[b]{2}{*}{$30^{\circ} \mathrm{C}$} \\
\hline & & $25^{\circ} \mathrm{C}$ & \\
\hline \multicolumn{4}{|l|}{ P. dentatus } \\
\hline 2.0 & $0.41(0.11)^{\mathrm{a}}$ & $0.53(0.15)^{\mathrm{a}}$ & $0.18(0.09)^{\mathrm{a}}$ \\
\hline 3.5 & $0.66(0.12)^{b}$ & $1.16(0.23)^{\mathrm{c}}$ & $0.62(0.20)^{b}$ \\
\hline 5.0 & $0.99(0.25)^{\mathrm{c}}$ & $1.45(0.32)^{\mathrm{d}}$ & $1.04(0.20)^{\mathrm{c}}$ \\
\hline 7.0 & $0.87(0.25)^{\mathrm{C}}$ & $1.49(0.30)^{\mathrm{d}}$ & $1.26(0.37)^{\mathrm{d}}$ \\
\hline $1.0-11.0$ & $0.99(0.17)^{\mathrm{C}}$ & $0.88(0.29)^{\mathrm{b}}$ & $0.59(0.27)^{\mathrm{b}}$ \\
\hline \multicolumn{4}{|c|}{ P. americanus } \\
\hline 2.0 & $0.07(0.11)^{\mathrm{a}}$ & $-0.11(0.30)^{\mathrm{a}}$ & \\
\hline 3.5 & $0.29(0.17)^{\mathrm{b}}$ & $0.04(0.08)^{b, c}$ & \\
\hline 5.0 & $0.27(0.10)^{\mathrm{b}}$ & $0.07(0.06)^{\mathrm{b}, \mathrm{c}}$ & \\
\hline 7.0 & $0.49(0.20)^{\mathrm{c}}$ & $0.04(0.04)^{\mathrm{a}, \mathrm{b}}$ & \\
\hline $1.0-11.0$ & $0.21(0.23)^{b}$ & $0.10(0.08)^{\mathrm{c}}$ & \\
\hline
\end{tabular}

tween individual DO treatments were only observed for summer flounder in the diel-cycling treatment at $25^{\circ} \mathrm{C}$ (Tukey's test, p < 0.05) (Fig. 1). While not statistically significant, there was a trend toward acclimation of both species when challenged by a combination of severely low DO and high temperature (winter flounder at $25^{\circ} \mathrm{C}$ and $2 \mathrm{mg} \mathrm{O}_{2} \mathrm{l}^{-1}$, and summer flounder at $30^{\circ} \mathrm{C}$ and 2.0 and $3.5 \mathrm{mg} \mathrm{O}_{2} \mathrm{l}^{-1}$ ).

Low DO significantly reduced feeding rates of summer and winter flounder at all temperatures (ANCOVA, $\mathrm{p}<0.05$ ). Furthermore, there was a significant linear relationship between FP and SGR for both species ( $p<0.05$ ) (Table 3). FP of summer flounder explained 36,44 , and $59 \%$ of the variability in SGR at 20, 25, and $30^{\circ} \mathrm{C}$, respectively. For winter flounder, FP explained $53 \%$ of the variability in SGR at $20^{\circ} \mathrm{C}$ (Table 3 ). The relationship between SGR and FP of winter flounder was weaker at $25^{\circ} \mathrm{C}\left(\mathrm{r}^{2}=0.22\right)$ (Table 3$)$. At this temperature, FP was relatively consistent across DO treatments greater than $2.0 \mathrm{mg} \mathrm{O}_{2} \mathrm{l}^{-1}$, but was zero at $2.0 \mathrm{mg} \mathrm{O}_{2} \mathrm{l}^{-1}$. There were no effects of hypoxia on AE of either species at any temperature (data not shown).

Low mortality was observed for both species in all experiments (see Table 3). One summer flounder died in the diel-cycling DO treatment at $25^{\circ} \mathrm{C}$, and 2 in the $2.0 \mathrm{mg} \mathrm{O} \mathrm{O}^{-1}$ treatment at $30^{\circ} \mathrm{C}$. One winter flounder died at $20^{\circ} \mathrm{C}\left(2.0 \mathrm{mg} \mathrm{O}_{2} \mathrm{l}^{-1}\right)$, but mortality increased at $25^{\circ} \mathrm{C}$ to 2 individuals in the diel-cycling treatment and 3 individuals in the $2.0 \mathrm{mg} \mathrm{O}_{2} \mathrm{l}^{-1}$ treatment.

Effects of salinity and DO on growth and consumption

There was a significant interaction between salinity and DO on SGR of summer flounder (ANCOVA, $\mathrm{p}<0.01$ ). At a salinity of $25 \%$, SGR was significantly reduced at $\leq 5.0 \mathrm{mg} \mathrm{O}_{2} \mathrm{I}^{-1}$ and under diel-cycling DO conditions, whereas at a salinity of $15 \%$, growth was reduced only at $2.0 \mathrm{mg} \mathrm{O} \mathrm{O}^{-1}$ (Fig. 3). As in the

Table 3. Paralichthys dentatus and Pseudopleuronectes americanus. Regression relationships between fecal production (FP: $x, g$ feces $\times g$ fish mass ${ }^{-1}$ ) and specific growth rate (SGR: $y, \%$ body mass $\mathrm{d}^{-1}$ ) of juvenile summer flounder and winter flounder at each temperature treatment. ${ }^{*}$ Significant difference $(p<0.01)$

\begin{tabular}{|llrc|}
\hline Temp. $\left({ }^{\circ} \mathrm{C}\right)$ & $\mathrm{n}$ & $\mathrm{r}^{2}$ \\
\hline $\boldsymbol{P . ~ d e n t a t u s}$ & & & \\
20 & $y=-0.412+182.8 x$ & 50 & $0.36^{*}$ \\
25 & $y=0.278+268.9 x$ & 49 & $0.44^{*}$ \\
30 & $y=-0.011+296.4 x$ & 48 & $0.59^{*}$ \\
P. americanus & & & \\
20 & $y=-0.690+347.4 x$ & 49 & $0.53^{*}$ \\
25 & $y=-0.221+80.6 x$ & 45 & $0.22^{*}$ \\
\hline
\end{tabular}




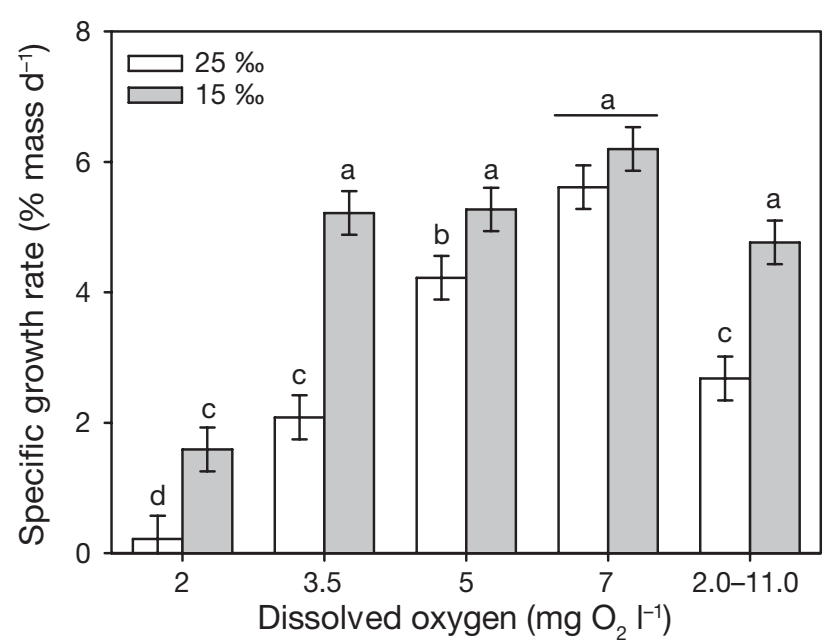

Fig. 3. Paralichthys dentatus. Specific growth rates (mean \pm $\mathrm{SE}$ ) of juvenile summer flounder at salinities of 15 and $25 \%$ at $30^{\circ} \mathrm{C}$. Bars with similar superscripts are not statistically different $(p>0.05)$

previous experiments, low DO significantly reduced FP of summer flounder at both salinities (ANCOVA, $\mathrm{p}<0.05)$. Again, there was a significant linear relationship between FP and SGR at both salinities $(p<0.05)$, with FP explaining 18 and $59 \%$ of the variability in SGR at salinities of 15 and $25 \%$, respectively.

\section{Effects of substrate and DO on growth}

The presence of a sand substrate had no significant effect on the growth response of summer flounder to hypoxia. Although SGR and LGR were reduced significantly at $2.0 \mathrm{mg} \mathrm{O} \mathrm{O}^{-1}$, there was no difference in growth rates between fishes with or without a sand substrate at 2.0 or $7.0 \mathrm{mg} \mathrm{O}_{2} \mathrm{l}^{-1}$ (Table 4). Although FP was not quantified in this experiment, fish in the sand treatments appeared to feed more readily than those in tanks without sand, but fish at $2.0 \mathrm{mg} \mathrm{O}_{2} \mathrm{l}^{-1}$ (in both substrate treatments) appeared to feed much less than those at normoxia.

Table 4. Paralichthys dentatus. Specific and linear growth rates of juvenile summer flounder after $7 \mathrm{~d}$ exposure to hypoxia at $25^{\circ} \mathrm{C}$ and a salinity of $25 \%$, both with and without sand substrate. Means with similar superscripts are not statistically different $(\mathrm{p}>0.05)$

\begin{tabular}{|lcccc|}
\hline $\begin{array}{l}\text { Treatment } \\
\left(\mathrm{mg} \mathrm{O}_{2} \mathrm{l}^{-1}\right)\end{array}$ & $\begin{array}{c}\text { Substrate } \\
\text { type }\end{array}$ & $\begin{array}{c}\text { Mean } \pm(\mathrm{SE}) \mathrm{DO} \\
\left(\mathrm{mg} \mathrm{O}_{2} \mathrm{l}^{-1}\right)\end{array}$ & $\begin{array}{c}\text { SGR } \\
\left(\% \mathrm{mass} \mathrm{d}^{-1}\right)\end{array}$ & $\begin{array}{c}\text { LGR } \\
\left(\mathrm{mm} \mathrm{d}^{-1}\right)\end{array}$ \\
\hline 2.0 & $\begin{array}{c}\text { Sand } \\
\text { No sand }\end{array}$ & $2.42(0.40)$ & $1.72(0.37)^{\mathrm{a}}$ & $0.75(0.15)^{\mathrm{a}}$ \\
7.0 & $\begin{array}{c}2.55(0.66) \\
\text { Sand }\end{array}$ & $6.66(0.75)$ & $5.73(0.39)^{\mathrm{a}}$ & $0.61(0.16)^{\mathrm{a}}$ \\
& No sand & $6.67(0.34)$ & $4.11(0.37)^{\mathrm{b}}$ & $1.90(0.15)^{\mathrm{b}}$ \\
& & & & \\
& & &
\end{tabular}

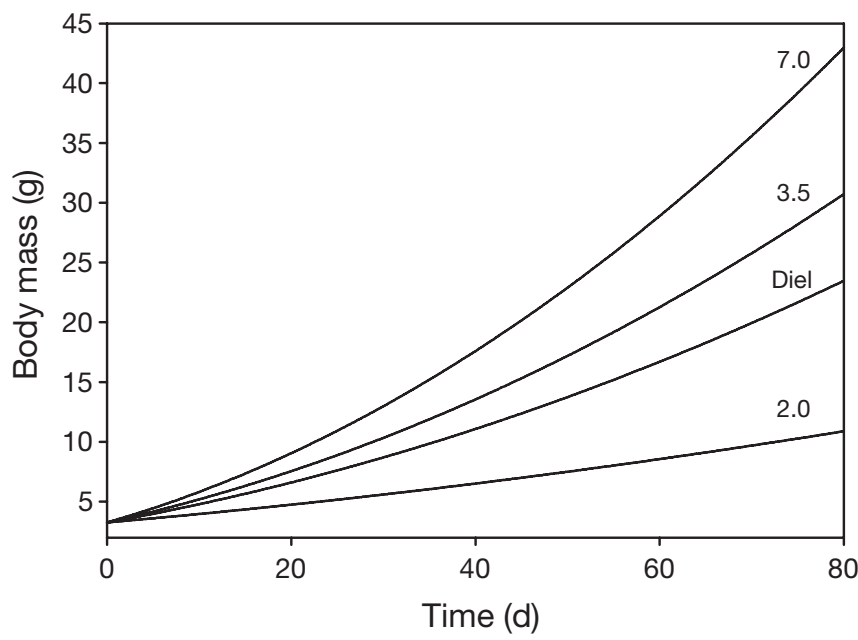

Fig. 4. Paralichthys dentatus. Modeled growth in mass of juvenile summer flounder under static $(2.0,3.5$, and $7.0 \mathrm{mg}$ $\mathrm{O}_{2} \mathrm{l}^{-1}$ ) and diel-cycling (2.0 to $11.0 \mathrm{mg} \mathrm{O} \mathrm{O}^{-1}$ ) ambient dissolved oxygen conditions for $80 \mathrm{~d}$

\section{Modeled and in situ growth of summer flounder}

In the model, juvenile summer flounder at $7.0 \mathrm{mg}$ $\mathrm{O}_{2} \mathrm{l}^{-1}$ increased in mass from 3.25 to $42.4 \mathrm{~g}$ after $80 \mathrm{~d}$ (Fig. 4). Final masses of summer flounder at $3.5 \mathrm{mg}$ $\mathrm{O}_{2} \mathrm{l}^{-1}$, diel-cycling, and $2.0 \mathrm{mg} \mathrm{O}_{2} \mathrm{l}^{-1}$ were reduced by 29,45 , and $74 \%$, respectively. Juvenile summer flounder at $7.0 \mathrm{mg} \mathrm{O}_{2} \mathrm{l}^{-1}$ increased in length from 60 to $180 \mathrm{~mm}$ after $80 \mathrm{~d}$ (Fig. 5). Final lengths of summer flounder at $3.5 \mathrm{mg} \mathrm{O}_{2} \mathrm{l}^{-1}$, diel-cycling, and $2.0 \mathrm{mg} \mathrm{O}_{2} \mathrm{l}^{-1}$ were reduced by 16,28 , and $45 \%$, respectively.

Juvenile summer flounder were present in Pepper Creek trawl samples between 9 May (Day 0 in the model) and 27 June 2001 (Day 49 in the model). The catch of summer flounder varied between trawling events $(1<\mathrm{n}<73$ fish per sample), but averaged 31 fish per sample. During this period, DO fluctuated on a diel cycle between 0.1 and $\sim 17 \mathrm{mg} \mathrm{O}_{2} \mathrm{l}^{-1}$ (Fig. 6). Mean TL of summer flounder in Pepper Creek on Day 49 was $110 \mathrm{~mm}$ (Fig. 5). The observed LGR of fish from Pepper Creek was significantly greater than modeled LGR at $2.0 \mathrm{mg} \mathrm{O} \mathrm{O}_{2}^{-1}(\mathrm{p}<0.001)$ and dielcycling conditions $(\mathrm{p}<0.05)$, was significantly less than modeled LGR at $7.0 \mathrm{mg} \mathrm{O} \mathrm{O}^{-1}(\mathrm{p}<0.001)$, and was not statistically different from modeled LGR at $3.5 \mathrm{mg} \mathrm{O}_{2} \mathrm{l}^{-1}(\mathrm{p}=0.07)$. Therefore, it appears that summer flounder were growing sub-optimally in Pepper Creek, and had growth rates comparable to those observed in the laboratory under moderately hypoxic conditions, and slightly greater than those growing under diel-cycling DO conditions. 


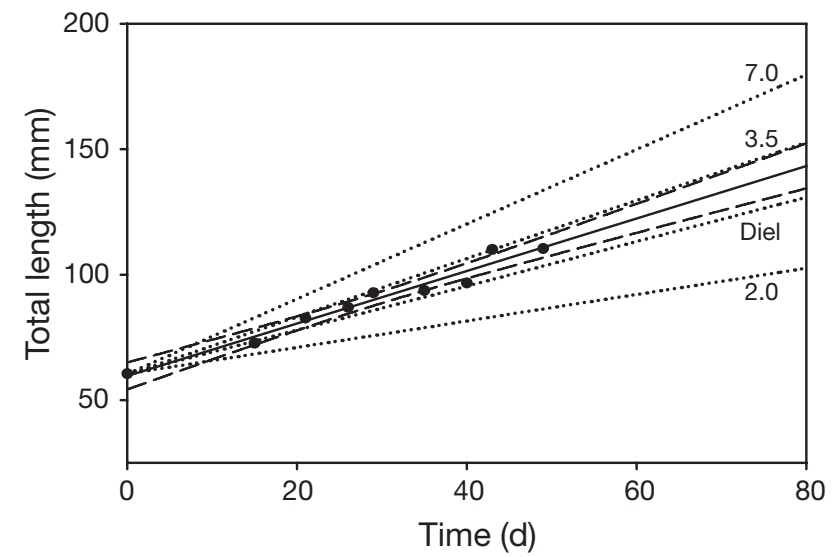

Fig. 5. Paralichthys dentatus. Modeled growth in length (dotted lines) of juvenile summer flounder under static $(2.0,3.5$, and $7.0 \mathrm{mg} \mathrm{O}_{2} \mathrm{l}^{-1}$ ) and diel-cycling (2.0 to $11.0 \mathrm{mg} \mathrm{O}_{2} \mathrm{l}^{-1}$ ) ambient dissolved oxygen conditions for $80 \mathrm{~d}$. Observed growth in total length (• and solid line) and 95\% confidence limits (dashed lines) of juveniles collected from Pepper Creek, Delaware Coastal Bays, between 9 May and 27 June 2001

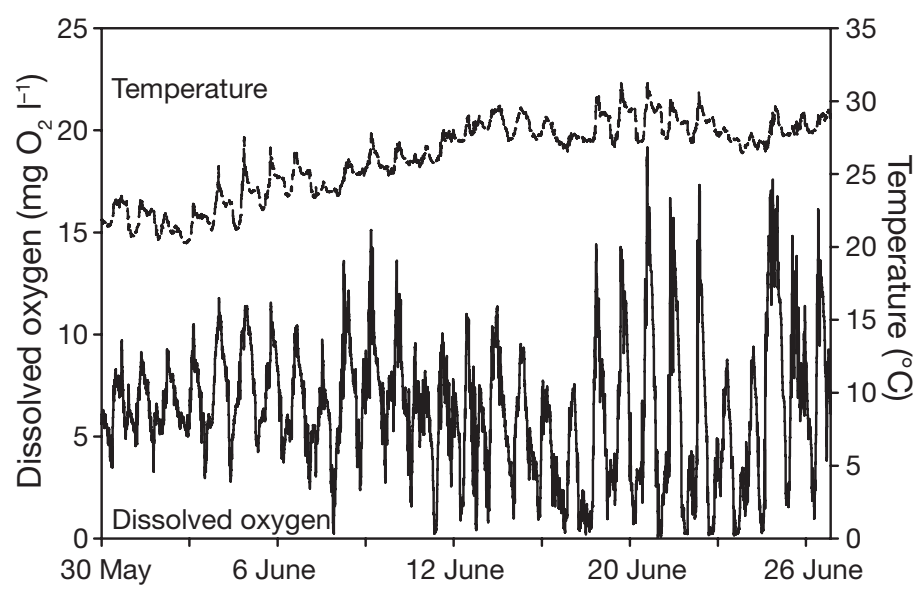

Fig. 6. Temperature and dissolved oxygen in Pepper Creek, Delaware Coastal Bays, from 30 May to 27 June 2001

\section{DISCUSSION}

\section{Environmental factors affecting growth during hypoxia}

Constant hypoxia induced significant reductions in the growth rate of juvenile summer and winter flounder after only $7 \mathrm{~d}$. For both species, growth limitation occurred under moderately hypoxic conditions (50 to $70 \%$ air saturation) that are well above lethal levels. Winter flounder were more sensitive to low DO than were summer flounder. Previous studies describe a $96 \mathrm{~h}$ median lethal concentration $\left(\mathrm{LC}_{50}\right)$ of 1.1 to $1.6 \mathrm{mg} \mathrm{O}_{2} \mathrm{l}^{-1}$ for summer flounder (Poucher \& Coiro 1997, Miller et al. 2002) and $\sim 1.4 \mathrm{mg} \mathrm{O}_{2} \mathrm{l}^{-1}$ for winter flounder (Poucher \& Coiro 1997). Diel-cycling hypoxia caused significant growth rate limitation in several of the experiments. The DO conditions that restricted growth in this study are common in estuarine environments. In their review of marine benthic hypoxia, Diaz \& Rosenberg (1995) considered DO concentrations between $100 \%$ air saturation and $2.0 \mathrm{mg} \mathrm{O}_{2} \mathrm{l}^{-1}$ ( $18 \%$ saturation) to be 'normoxic'. Data obtained from our study emphasize how even brief periods of intermediate hypoxia can have substantial effects on growth, and thus potentially reduce nursery habitat quality.

Temperature appears to play a significant role in the growth response of both species to hypoxia. As temperature increased, growth rates became increasingly sensitive to reduced DO concentrations. At $30^{\circ} \mathrm{C}$, growth of juvenile summer flounder was reduced by $\sim 90 \%$ at $2.0 \mathrm{mg} \mathrm{O}_{2} \mathrm{l}^{-1}$. Juvenile winter flounder grew poorly at all DO levels tested at $25^{\circ} \mathrm{C}$, and fish lost mass at $2.0 \mathrm{mg} \mathrm{O}_{2} \mathrm{l}^{-1}$. Due to high mortality of winter flounder during acclimation, we were unable to test this species at $30^{\circ} \mathrm{C}$. The temperature treatments used in this study were chosen to represent temperatures that would be encountered by these species in MidAtlantic Bight estuaries during the summer nursery season. The $30^{\circ} \mathrm{C}$ treatment substantially exceeds the optimal temperature for growth of summer flounder $\left(22^{\circ} \mathrm{C}\right)$, and can cause significant mortality in juvenile summer flounder (Howson 2000). The $25^{\circ} \mathrm{C}$ treatment approaches the upper incipient lethal temperature of $27^{\circ} \mathrm{C}$ for winter flounder (Casterlin \& Reynolds 1982), and is much higher than their preferred temperature of $18^{\circ} \mathrm{C}$ (McCracken 1963). Therefore, hypoxia likely becomes increasingly important in limiting the suitability of certain habitats as nurseries for estuarydependent fishes as temperatures approach or exceed their optimal temperatures and/or in the southern portion of their geographic range. A similar growth response of juvenile spot Leiostomus xanthurus (McNatt \& Rice 2004) and striped bass Morone saxatilis (Cech et al. 1984) to the combination of high temperature and low DO further supports this notion.

Salinity may also influence the effect of hypoxia on nursery quality. The negative effect of hypoxia on growth of summer flounder appeared to be reduced at lower salinity (15 vs. $25 \%$ salinity). This was somewhat unexpected, as a previous study on juvenile summer flounder (Howson 2000) had reported maximum growth rate and increased gross growth efficiency at a salinity of $24 \%$, with growth rate (and growth efficiency) declining at lower salinity. However, studies on other fishes have shown growth rate and growth efficiency to be greatest at mesohaline salinities (Lankford \& Targett 1994, Imsland et al. 2001), which was attributed to decreased energetic costs of ionic and osmotic regulation at intermediate salinities (e.g. 10 to $15 \%$ ) 
that approximate the osmotic pressure of internal body fluids (Imsland et al. 2001). Therefore, it might be expected that the effects of hypoxia may be more pronounced at lower (or higher) salinity. Further work across a range of salinity, DO, and temperature is required to more fully develop any generalizations regarding such a potential interaction.

Fish in this study were grown in tanks that lacked a sand substrate, to (1) facilitate the recovery of fecal material for estimates of feeding rate, and (2) minimize potential water quality problems associated with the incomplete removal of uneaten food. Howell \& Canario (1987) observed that resting metabolic rates of sole Solea solea reared without substrate were nearly double those reared in the presence of sand, owing in part to the fishes' efforts to bury in the absence of sediment. Therefore, an increase in metabolism of flatfish in this and other studies without substrate could have confounding effects on growth rate estimates by partitioning more energy toward burying activity and away from growth. Although metabolic rate was not measured in the present study, we observed no significant effect of substrate on growth of summer flounder under either saturated or hypoxic conditions, nor did we observe any unusual amount of burial activity in this or any of the other experiments (authors' pers. obs.). These data suggest that lack of sand substrate did not influence the growth response of either species to hypoxia.

Reduction in feeding rate appears to be a major cause of the hypoxia-induced decline in growth rate of these 2 flatfishes. No differences in absorption efficiency were found for either species across DO treatments. Feeding rates of summer and winter flounder explained as much as $59 \%$ of the variability in growth rate, suggesting that reduced growth rates were largely due to decreased consumption rates. Several other studies have observed decreased growth rates under hypoxic conditions, which were attributed in part to reduced consumption. For example, growth of Atlantic cod Gadus morhua was directly related to \% oxygen saturation, and feeding rate explained $97 \%$ of the variability in growth rate (Chabot \& Dutil 1999). In addition, Pichavant et al. (2001) found no difference in growth between juvenile turbot Scophthalmus maximus fed ad lib under hypoxic conditions and those held under normoxia, and fed a restricted ration similar to the amount of food consumed in the hypoxic treatment, indicating that decreased feeding likely caused the observed reduction in growth. Due to the substantial (up to 5-fold) increase in oxygen consumption after feeding (Pichavant et al. 2001), reduced consumption is thought to be a behavioral strategy for conserving energy and maximizing metabolic scope during hypoxia (Brett \& Groves 1979).

\section{Compensatory growth and acclimation to hypoxia}

Growth rate acclimation may be a physiological mechanism by which fishes are adapted to minimize the negative effects of prolonged sub-lethal hypoxia on growth. For example, juvenile southern flounder Paralichthys lethostigma appeared to acclimate to hypoxic conditions by exhibiting significantly faster growth during the third week of a $21 \mathrm{~d}$ exposure to $2.8 \mathrm{mg} \mathrm{O}_{2} \mathrm{l}^{-1}$ (Taylor \& Miller 2001). In contrast, in the present study, neither summer flounder nor winter flounder acclimated to low DO after 7 to $14 \mathrm{~d}$ exposure to varying degrees of hypoxia. In fact, summer flounder at $25^{\circ} \mathrm{C}$ and winter flounder at $20^{\circ} \mathrm{C}$ grew significantly slower during the second week of the experiment. It is possible that the $14 \mathrm{~d}$ exposure time in this study was not adequate to observe acclimation. For instance, mummichog Fundulus heteroclitus acclimated to hypoxia, but only after 14 to $28 \mathrm{~d}$ at 1.5 to $2.5 \mathrm{mg} \mathrm{O}_{2} \mathrm{l}^{-1}$ (Greaney et al. 1980). However, the trend toward slower growth after 7 to $14 \mathrm{~d}$ in the present study suggests that short- to intermediate-term growth acclimation of either species is improbable.

Compensatory growth may be another means to overcome negative effects of hypoxia on growth. Bejda et al. (1992) exposed juvenile winter flounder to 2.2 and $6.7 \mathrm{mg} \mathrm{O}_{2} \mathrm{l}^{-1}$ for $11 \mathrm{wk}$, after which $\mathrm{DO}$ in the hypoxic treatment was returned to normoxic levels and growth of both groups was tracked for an additional 5 wk. In that study, winter flounder from the previously hypoxic treatment exhibited growth rates more than twice those of fishes from the normoxic treatment and, after $5 \mathrm{wk}$, reached a comparable size to the fishes grown continuously at normoxia. In many cases, chronic (Officer et al. 1984) or diel-cycling hypoxia (D'Avanzo \& Kremer 1994, Tyler 2004) conditions like those tested by Bejda et al. (1992) persist throughout the summer months, and span the nursery period for many estuary-dependent fishes (May to September). In the fall, DO conditions typically improve and compensatory growth could benefit fishes surviving to that point. However, significant reductions in summertime growth, and increased mortality during post-settlement and early juvenile stages where size-selective predation is likely greater, would minimize the overall effect of potential compensatory growth in the fall.

\section{Ecological implications of hypoxia for estuarine nurseries}

Our models of juvenile summer flounder growth (in length and mass) over a range of DO conditions illustrate the potential result of long-term hypoxia on decreased size-at-age. In addition, the correspondence 
of predicted and observed lengths of juvenile summer flounder exposed to diel-cycling hypoxia in Pepper Creek suggests that those fishes were growing suboptimally. Houde (1987) illustrated that as little as a $25 \%$ change in daily mortality or growth rates could affect subsequent recruitment in young fishes 3- to 10 -fold. Therefore, modest reductions in growth rates caused by sub-lethal hypoxia may have substantial effects on survival, and greatly reduce nursery habitat quality for estuary-dependent flatfishes.

The ability of fishes to detect and avoid areas of low DO may act to minimize the negative effects of hypoxia on growth of young fishes in estuarine nurseries (Wannamaker \& Rice 2000). However, DO concentrations that resulted in growth limitation in this study were well above those that elicit an avoidance response in previous laboratory studies. For example, juvenile winter flounder avoided DO concentrations of $2.0 \mathrm{mg} \mathrm{O}_{2} \mathrm{l}^{-1}$ (Rager 2002), but experienced significant growth limitation at $5.0 \mathrm{mg} \mathrm{O}_{2} \mathrm{l}^{-1}$. Similarly, juvenile summer flounder avoided $1.0 \mathrm{mg} \mathrm{O}_{2} \mathrm{l}^{-1}$ (Tyler 2004), but had significantly reduced growth between 3.5 and $5.0 \mathrm{mg} \mathrm{O} \mathrm{I}^{-1}$. While the avoidance of severely hypoxic waters may reduce the likelihood of mortality, moderately hypoxic and sub-lethal DO conditions may still impose substantial limitations on growth of fishes in those habitats.

The observed effects of hypoxia on growth of both species in the laboratory and the apparent growth limitation of summer flounder in Pepper Creek collectively stress the potentially negative effects of moderate to severe hypoxia on growth rates of these fishes, and the effect of continued eutrophication and worsening DO conditions on the overall quality of estuarine nursery habitats. Pepper Creek is a shallow mesohaline creek that experiences extreme diel cycles of DO during summer months. Previous studies have examined habitat-related differences in growth rates of caged juvenile winter flounder (Phelan et al. 2000, Meng et al. 2001) and tautog Tautoga onitis (Phelan et al. 2000) relative to environmental conditions in similar estuarine habitats. Although DO was not studied extensively in either of those studies, hypoxia was mentioned as a potential cause of observed differences in growth between habitats. While experimental data, like those presented here, provide valuable information on causes and potential consequences of growth limitation and interspecific differences in hypoxia tolerance, laboratory conditions (e.g. fish handling, prey quantity and quality, and lack of predators) limit direct comparisons between laboratory and field growth rates, and direct assessment of growth limitation in the wild. In this regard, future studies that explicitly examine the relationship between DO and direct growth estimates of juvenile estuary-dependent fishes in situ are critical in order to better understand the effects of habitat degradation on estuarine nursery habitats.

Despite the frequency and severity of low oxygen events in shallow estuaries and salt marsh creeks, and their potential limitations on growth, these habitats still continue to support high abundances of juvenile fishes, and for that reason (among others) are still considered valuable nurseries (Weinstein 1979). These shallow habitats have been shown to have relatively fewer piscivorous predators compared to adjacent open water habitats (Paterson \& Whitfield 2000), suggesting a potential refuge from predation in these habitats. Several studies observed that fishes were more abundant in habitats that supported slower growth rates (Sogard 1994, Ross 2003), and came to the same general conclusion that a potential trade-off exists between maximizing growth rate and minimizing the risk of predation. Considering the low mortality observed in summer and winter flounder after the $14 \mathrm{~d}$ exposure to severely low DO, these fishes appear capable of tolerating hypoxic conditions (despite experiencing growth limitation even at only moderate hypoxia) and exploiting the predator refuge that these hypoxic habitats may provide.

Acknowledgements. We thank D. Brady, J. Rager, R. Tyler, $\mathrm{S}$. Brown, and D. Tuzzolino for their assistance throughout the entirety of this study. We also thank R. Tyler for providing the Paralichthys dentatus length data and DO data used in the model analysis. J. Rice and P. Grecay made helpful suggestions on the research and comments on an earlier draft of this manuscript. The comments of 2 anonymous reviewers are also appreciated. This research was supported by funding from the National Sea Grant Office, NOAA, and US Department of Commerce under grant numbers NA96RG0029 (Project R/F-17), NA16RG0162-03 (Project R/F-21), and NA03OAR4170011 (Project R/F-23) to T.E.T., a Research Scholarship from the Delaware Mobile Surf-Fishermen to K.L.S., and summer research fellowships from the University of Delaware Science and Engineering Scholars Program to K.M.

\section{LITERATURE CITED}

Able KW (1999) Measures of juvenile fish habitat quality: examples from a National Estuarine Research Reserve. Am Fish Soc Symp 22:134-147

Anderson JT (1988) A review of size dependent survival during pre-recruit stages of fishes in relation to recruitment. J Northwest Atl Fish Sci 8:55-66

Beck MW, Heck KL, Able KW, Childers DL and 9 others (2001) The identification, conservation, and management of estuarine and marine nurseries for fish and invertebrates. Bioscience 51:633-641

Bejda AJ, Phelan BA, Studholme AL (1992) The effect of dissolved oxygen on the growth of young-of-the-year winter flounder, Pseudopleuronectes americanus. Environ Biol Fish 34:321-327

Bell GW, Eggleston DB (2005) Species-specific avoidance responses by blue crabs and fish to chronic and episodic hypoxia. Mar Biol 146:761-770 
Brett JR, Groves TDD (1979) Physiological energetics. In: Hoar WS, Randall DJ, Brett JR (eds) Fish physiology, Vol VIII. Academic Press, Orlando, FL, p 279-352

Bricker SB, Clement CG, Pirhalla DE, Orlando SP, Farrow DRG (1999) National estuarine eutrophication assessment: effects of nutrient enrichment in the nation's estuaries, NOAA, National Ocean Service, Special Projects Office and the National Centers for Coastal Ocean Science, Silver Spring, MD

Casterlin ME, Reynolds WW (1982) Thermoregulatory behavior and diel activity of yearling winter flounder, Pseudopleuronectes americanus (Walbaum). Environ Biol Fish 7:177-180

Cech JJ Jr, Mitchell SJ, Wragg TE (1984) Comparative growth of juvenile white sturgeon and striped bass-effects of temperature and hypoxia. Estuaries 7:12-18

Chabot D, Dutil JD (1999) Reduced growth of Atlantic cod in non-lethal hypoxic conditions. J Fish Biol 55:472-491

D'Avanzo C, Kremer JN (1994) Diel oxygen dynamics and anoxic events in an eutrophic estuary of Waquoit Bay, Massachusetts. Estuaries 17:131-139

Diaz RJ (2001) Overview of hypoxia around the world. J Environ Qual 30:275-281

Diaz RJ, Rosenberg R (1995) Marine benthic hypoxia: a review of its ecological effects and the behavioural responses of benthic macrofauna. Oceanogr Mar Biol Annu Rev 33:245-303

Eby LA, Crowder LB (2002) Hypoxia-based habitat compression in the Neuse River Estuary: context-dependent shifts in behavioral avoidance thresholds. Can J Fish Aquat Sci 59:952-965

Gibson RN (1994) Impact of habitat quality and quantity on the recruitment of juvenile flatfishes. Neth J Sea Res 32:191-206

Greaney GS, Place AR, Cashon RE, Smith G, Powers DA (1980) Time course of changes in enzyme activities and blood respiratory properties of killifish during long-term acclimation to hypoxia. Physiol Zool 53:136-144

Grecay PA, Stierhoff KL (2002) A device for simultaneously controlling multiple treatment levels of dissolved oxygen in laboratory experiments. J Exp Mar Biol Ecol 280:53-62

Hoss DE, Thayer GW (1993) The importance of habitat to the early life history of estuarine dependent fishes. Am Fish Soc Symp 14:147-158

Houde ED (1987) Fish early life dynamics and recruitment variability. Am Fish Soc Symp 2:17-29

Houde ED (1989) Subtleties and episodes in the early life of fishes. J Fish Biol 35(Suppl A):29-38

Howell BR, Canario AVM (1987) The influence of sand on the estimation of resting metabolic rate of juvenile sole, Solea solea (L). J Fish Biol 31:277-280

Howson UA (2000) Nursery habitat quality for juvenile paralichthyid flounders: experimental analyses of the effects of physicochemical parameters. PhD thesis, University of Delaware, Newark, DE

Imsland AK, Foss A, Gunnarsson S, Berntssen MHG and 5 others (2001) The interaction of temperature and salinity on growth and food conversion in juvenile turbot (Scophthalmus maximus). Aquaculture 198:353-367

Joseph EG (1973) Analyses of a nursery ground. In: Pacheco AL (ed) Proceedings of a workshop on egg, larval and juvenile stages of fish in Atlantic coast estuaries. MidAtlantic Coastal Fish Center, Highlands, NJ, p 118-121

Kennish MJ (2002) Environmental threats and environmental future of estuaries. Environ Conserv 29:78-107

Kramer DL (1987) Dissolved oxygen and fish behavior. Environ Biol Fish 18:81-92
Lankford TE Jr, Targett TE (1994) Suitability of estuarine nursery zones for juvenile weakfish (Cynoscion regalis): effects of temperature and salinity on feeding, growth and survival. Mar Biol 119:611-620

McCracken FD (1963) Seasonal movements of the winter flounder, Pseudopleuronectes americanus (Walbaum) on the Atlantic coast. J Fish Res Board Can 20:551-586

McNatt RA, Rice JA (2004) Hypoxia-induced growth rate reduction in two juvenile estuary-dependent fishes. J Exp Mar Biol Ecol 311:147-156

Meng L, Powell JC, Taplin B (2001) Using winter flounder growth rates to assess habitat quality across an anthropogenic gradient in Narragansett Bay, Rhode Island. Estuaries 24:576-584

Miller DC, Poucher SL, Coiro L (2002) Determination of lethal dissolved oxygen levels for selected marine and estuarine fishes, crustaceans, and a bivalve. Mar Biol 140:287-296

Miller JM, Crowder LB, Moser ML (1985) Migration and utilization of estuarine nurseries by juvenile fishes: an evolutionary perspective. In: Rankin MA, Checkley D, Cullen J, Kitting $C$, Thomas $P$ (eds) Contributions in marine science. Marine Science Institute, Port Aransas, TX, p 338-352

Minello TJ (1999) Nekton densities in shallow estuarine habitats of Texas and Louisiana and the identification of essential fish habitat. Am Fish Soc Symp 22:43-75

NRC (National Research Council) (2000) Clean coastal waters: understanding and reducing the effects of nutrient pollution. National Academy Press, Washington, DC

Officer CB, Biggs RB, Taft JL, Cronin LE, Tyler MA, Boynton WR (1984) Chesapeake Bay anoxia: origin, development, and significance. Science 223:22-26

Packer DB, Hoff T (1999) Life history, habitat parameters and essential habitat of mid-Atlantic summer flounder. Am Fish Soc Symp 22:76-92

Paerl HW, Pinckney JL, Fear JM, Peierls BL (1998) Ecosystem responses to internal and watershed organic matter loading: consequences for hypoxia in the eutrophying Neuse River Estuary, North Carolina, USA. Mar Ecol Prog Ser 166: $17-25$

Paterson AW, Whitfield AK (2000) Do shallow-water habitats function as refugia for juvenile fishes? Estuar Coast Shelf Sci 51:359-364

Phelan BA, Goldberg R, Bejda AJ, Pereira J and 5 others (2000) Estuarine and habitat-related differences in growth rates of young-of-the-year winter flounder (Pseudopleuronectes americanus) and tautog (Tautoga onitis) in three northeastern US estuaries. J Exp Mar Biol Ecol 147:1-28

Pichavant K, Person-Le Ruyet J, Le Bayon N, Severe A, Le Roux A, Boeuf G (2001) Comparative effects of long-term hypoxia on growth, feeding and oxygen consumption in juvenile turbot and European sea bass. J Fish Biol 59: 875-883

Poucher SL, Coiro L (1997) Test reports: effects of low dissolved oxygen on saltwater animals, memorandum to D.C. Miller. US Environmental Protection Agency, Atlantic Ecology Division, Narragansett, RI

Rager JD (2002) Avoidance behavior of juvenile striped bass and winter flounder in response to various degrees of hypoxia. Undergraduate thesis, University of Delaware, Newark, DE

Richards CE, Castagna M (1970) Marine fishes of Virginia's eastern shore (inlet and marsh, seaside waters). Chesapeake Sci 11:235-248

Ricker WE (1975) Computation and interpretation of biological statistics of fish populations. Department of the Environment, Fisheries and Marine Science, Ottawa 
Ross SW (2003) The relative value of different estuarine nursery areas in North Carolina for transient juvenile marine fishes. Fish Bull 101:384-404

Seliger HH, Boggs JA, Biggley WH (1985) Catastrophic anoxia in the Chesapeake Bay in 1984. Science 228: 70-73

Sogard SM (1994) Use of suboptimal foraging habitats by fishes: consequences to growth and survival. In: Stouder DJ, Fresh KL, Feller RJ (eds) Theory and application of fish feeding ecology. University of South Carolina Press, Columbia, SC, p 103-132

Sogard SM (1997) Size-selective mortality in the juvenile stage of teleost fishes: a review. Bull Mar Sci 60:1129-1157

Stierhoff KL, Targett TE, Grecay PA (2003) Hypoxia tolerance of the mummichog: the role of access to the water surface. J Fish Biol 63:580-592

Taylor JC, Miller JM (2001) Physiological performance of juvenile southern flounder, Paralichthys lethostigma (Jordan and Gilbert, 1884), in chronic and episodic hypoxia. J Exp Mar Biol Ecol 258:195-214

Editorial responsibility: Erik Bonsdorff (Contributing Editor), Turku/Abo, Finland
Tyler RM (2004) Distribution and avoidance patterns of juvenile summer flounder (Paralichthys dentatus) and weakfish (Cynoscion regalis) in relation to hypoxia: field studies in a temperate coastal lagoon tributary and laboratory choice-trial experiments. $\mathrm{PhD}$ thesis, University of Delaware, Newark, DE

US EPA (US Environmental Protection Agency) (2000) Ambient aquatic life water quality criteria for dissolved oxygen (Saltwater): Cape Cod to Cape Hatteras. Report No. EPA-822-R-00-012. US Environmental Protection Agency, Narrangansett, RI

Wannamaker CM, Rice JA (2000) Effects of hypoxia on movements and behavior of selected estuarine organisms from the southeastern United States. J Exp Mar Biol Ecol 249: 145-163

Weinstein MP (1979) Shallow marsh habitats as primary nurseries for fishes and shellfish, Cape Fear River, North Carolina. Fish Bull 77:339-357

Yamashita Y, Tanaka M, Miller JM (2001) Ecophysiology of juvenile flatfish in nursery grounds. J Sea Res 45:3-4

Submitted: December 6, 2005; Accepted: April 7, 2006

Proofs received from author(s): October 16, 2006 